\title{
CROSSLINKING OF EPOXY-OLIGOESTERIC MIXTURES IN THE PRESEN CE OF DIOXYDIPHENYLPROPANE DIGLYCIDYL ETHER MODIFIED WITH ADIPIC ACID
}

\author{
Michael Bratychak ${ }^{1, *}$, Olga Zubal ${ }^{1}$, Bogdana Bashta ${ }^{2}$, Ostap Ivashkiv ${ }^{1}$, \\ Olena Shyshchak ${ }^{1}$, Jozef Haponiuk ${ }^{3}$
}

https://doi.org/10.23939/chcht11.02.180

\begin{abstract}
Crosslinking of epoxy-oligoesteric mixtures composed of ED-20 dianic epoxy resin and TGM-3 oligoesteracrylate has been studied in the presence of dioxydiphenylpropane diglycidyl ether modified with adipic acid (DCDER). Crosslinking was carried out at room temperature and while heating at 383,403 or $423 \mathrm{~K}$ using polyethylene polyamine as a hardener. The procedure of DCDER synthesis has been developed. The structural changes were controlled by determining film hardness and gel-fraction content. The chemistry of films formation was confirmed by IR-spectroscopy.
\end{abstract}

Keywords: crosslinking, polymer films, epoxy resin, oligoesteracrylate, hardness, gel-fraction, IR-spectroscopy.

\section{Introduction}

Epoxy resins and mixtures based on them are widely used as protective coatings, glues, compounds, etc. [1]. Despite high hardness, mechanical strength, thermal stability, good protective and dielectric properties, the wares based on epoxy resins have a low adhesion to color metals and elasticity [2]. To eliminate the mentioned defects the epoxy resins are chemically modified with various low- and high-molecular compounds [3, 4]. The resins are modified at the stage of functional oligomer obtaining, as well as at the stage of resulting product forming due to the adding different functional groups [3-5].

\footnotetext{
${ }^{1}$ Lviv Polytechnic National University

12, S.Bandery St., 79013 Lviv, Ukraine

${ }^{2}$ Institute of Macromolecular Chemistry AS CR

Heyrovskeho nam.2, CZ-16206 Praha 6, Czech Republic

${ }^{3}$ Gdansk University of Technology,

11/12 G. Narutowicza St., 80233 Gdansk, Poland

*mbratychak@gmail.com

(C) Bratychak M., Zubal O., Bashta B., Ivashkiv O., Shyshchak O., Haponiuk J., 2017
}

Recently the researches of the Department of Petroleum Chemistry and Technology (Lviv Polytechnic National University, Lviv Ukraine) carried out chemical modification of epoxy resins by unsaturated [6] and saturated acids [7], glycols [8, 9], hydroperoxides [10]. The modified epoxy compounds contain free epoxy and other functional groups, namely carboxy, primary hydroxy, peroxy, acrylate fragment. The modified resins can be used as additives to ED-20 industrial epoxy resin (10-30 wt \%) when producing protective coatings. The result of modified resins addition is the increase in adhesion to the metal surface and chemical resistance to aggressive media. The increase in adhesion is explained by esteric groups formation during polymer crosslinking; and high chemical resistance occurs due to the high content of gel-fraction in the crosslinked product.

In the present work we synthesize the additive with two carboxy groups as distinct from the known compound [6] and study its properties during epoxy-oligoesteric mixtures crosslinking.

\section{Experimental}

\section{1. $M$ aterials}

For DCDER synthesis we used Bisphenol A diglycidyl ether (DGEBA, Sigma Aldrich, USA) and adipic acid (AA, Dupont, USA). Benzyltriethylammonium chloride (BTEACh), used as a catalyst, was purchased from Sigma Aldrich, USA. The molecular mass of ED-20 epoxy dianic resin was $390 \mathrm{~g} / \mathrm{mol}$ and epoxy groups content was $20.0 \%$. TGM-3 oligoesteracrylate used as a plasticizer was used as received without additional purification; its molecular mass was $280 \mathrm{~g} / \mathrm{mol}$. Polyethylene polyamine (PEPA) was a hardener. It was used as received, without additional purification.

\subsection{M ethods of Analysis}

Molecular mass $\left(M_{n}\right)$ of the initial and synthesized products was determined using cryoscopy in dioxane [11]. 
The content of epoxy and carboxy groups (\%) was determined using a back titration method [12].

The concentration of epoxy groups was determined according to Eq. (1):

$$
[C]_{\text {e.g. }}=\frac{\left(V_{\text {blank }}-V_{\text {sample }}-V_{\text {acid }}\right) \cdot N \cdot K}{V_{s}}
$$

where $[C]_{\text {e.g. }}-$ concentration of epoxy groups in the reaction medium, mol/l; $V_{\text {blank }}-$ quantity of $0.1 \mathrm{~N} \mathrm{KOH}$ solution for the titration of blank sample, $\mathrm{ml} ; V_{\text {sample }}-$ quantity of $0.1 \mathrm{~N} \mathrm{KOH}$ solution for the titration of the sample withdrawn from the reaction medium, $\mathrm{ml} ; V_{\text {acid }}-$ quantity of $0.1 \mathrm{~N} \mathrm{KOH}$ solution for the titration of acid groups in the sample withdrawn from the reaction medium, $\mathrm{ml} ; N$ - normality of $\mathrm{KOH}$ solution equal to 0.1 ; $K$ - correction coefficient for $0.1 \mathrm{~N} \mathrm{KOH}$ solution; $V_{s}-$ sample volume equal to $0.5 \mathrm{ml}$.

The film hardness ( $H$, rel.units) was determined using M-3 pendulum device according to the standard procedure [12]. The gel-fraction content $(G, \%)$ was determined by extraction of grinded samples with acetone in Soxhlet apparatus for $12 \mathrm{~h}$ [13].

For IR-spectroscopic investigations we used Nicolet 8700 spectrophotometer (Thermal Electron Corporation) equipped with Specac Golden Gate adapter with ATR diamond crystal. The samples were prepared as thin films placed between two plates with $\mathrm{KBr}$ and spectra were recorded. Then the plates were placed into a desiccator, kept at room temperature for $24 \mathrm{~h}$ and again spectra were recorded. The next spectra were recorded while film heating at 383,403 ot $423 \mathrm{~K}$ every $15 \mathrm{~min}$.

\subsection{Crosslinking of Epoxy-Oligoesteric Mixtures}

All components and PEPA were mixed under vacuum to prepare epoxy-oligoesteric mixtures. The obtained mixture was poured over standard glass plates. Films formation was studied using two methods. With accordance to the first method the films were kept at room temperature for 1-10 days. According to the second method the mixture crosslinking was carried out stepwise: first at room temperature for $24 \mathrm{~h}$ and then while heating at different temperatures for $75 \mathrm{~min}$. The process was controlled by film hardness and gel-fraction content values.

\section{Results and Discussion}

\subsection{DCDER Synthesis}

DCDER was synthesized according to Eq. (2). For the development of DCDER synthesis procedure we used our previous results about chemical modification of epoxides by carbonic acids [6]. BTEACh was used as a catalyst of Eq. (2). The mixture composed of toluene and isopropyl alcohol was a reaction medium. The process temperature was $353 \mathrm{~K}$. The change of epoxy groups concentration depending on time during interaction of DGEBA and AA is represented in Fig. 1.

One can see from Fig. 1 that after $2.5 \mathrm{~h}$ the concentration of epoxy groups in the reaction mixture decreases twice and after $4 \mathrm{~h}$ almost all epoxy groups are used.

Procedure of DCDER synthesis

DCDER synthesis according to Eq. (2) was carried out in a three-necked reactor equipped with a mechanical stirrer, back condenser, drop tunnel and thermometer. $120 \mathrm{~g}$ of DGEBA dissolved in $400 \mathrm{ml}$ of toluene was loaded into the reactor together with $22.8 \mathrm{~g}$ of BTEAX dissolved in $10 \mathrm{ml}$ of $\mathrm{H}_{2} \mathrm{O}$. The mixture was heated to $353 \mathrm{~K}$ under constant stirring and $48.8 \mathrm{~g}$ of AA dissolved in $400 \mathrm{ml}$ of isopropyl alcohol was added dropwise for $1.5 \mathrm{~h}$. Then the mixture was stirred for another $3 \mathrm{~h}$, cooled to room temperature and transferred to the separating tunnel. $200 \mathrm{ml}$ of benzene was added to the tunnel, mixed and products were separated. The bottom layer was poured off and upper (organic) layer was washed by water to separate the catalyst. To control this process the solution $\mathrm{pH}$ was determined.

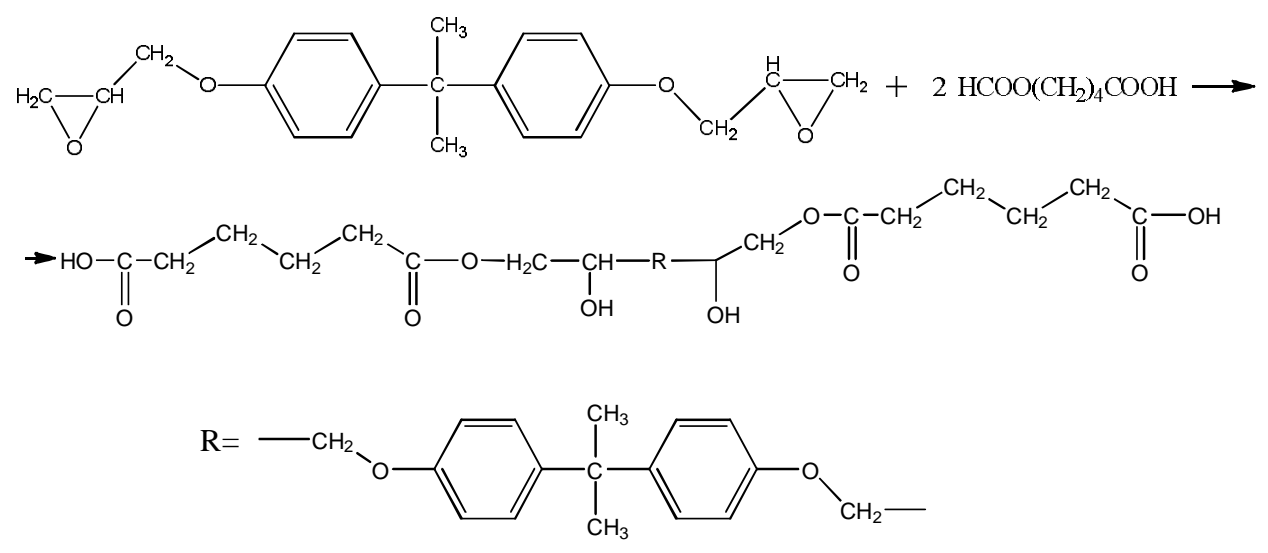






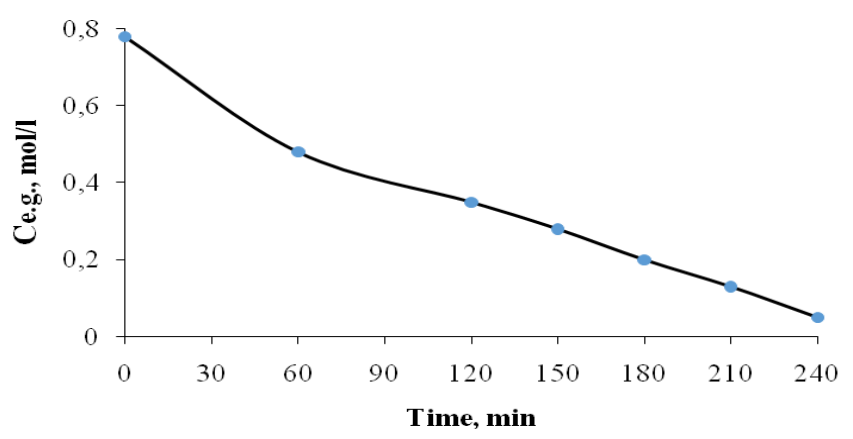

Fig. 1. The change of epoxy groups concentration $v$ s. reaction time at $353 \mathrm{~K}$. Catalyst quantity is $30 \mathrm{~mol} \%$ per $1 \mathrm{~g}$-eq. of AA carboxy groups.

\section{Molar ratio DGEBA:AA $=1: 2$}

The organic layer was distilled under vacuum (temperature is $323 \mathrm{~K}$, residual pressure is $133-266 \mathrm{~Pa}$ ). DCDER yield was $90.1 \%(152 \mathrm{~g})$. The product is dissolved in acetone, dioxane, alcohols and other organic solvents. It was found for DCDER: $M_{n} 720 \mathrm{~g} / \mathrm{mol}$; content of carboxy groups $8.6 \%$. The presence of carboxy groups and formation of hydroxy groups according to Eq. (2) is confirmed by absorption band at $3456 \mathrm{~cm}^{-1}$; esteric bond by absorption bands at $1732\left(v_{\mathrm{C}=\mathrm{O}}\right), 1256\left(v_{\mathrm{C}-\mathrm{O}-\mathrm{Oas}}\right)$ and $1048\left(v_{\mathrm{C}-\mathrm{O}-\mathrm{Csym}}\right) \mathrm{cm}^{-1}$. Such bonds can be formed only due to the chemical interaction of DGEBA epoxy ring and AA carboxy group followed by $-\mathrm{C}(\mathrm{O}) \mathrm{O}-\mathrm{CH}_{2}-$ fragment origination. The presence of DGEBA fragments in the synthesized product is confirmed by absorption bands at 1384 and $1360 \mathrm{~cm}^{-1}$ corresponding to the stretch vibrations of $-\mathrm{C}\left(\mathrm{CH}_{3}\right)_{3}-$ group. The presence of benzene rings is confirmed by the bands at 1608 and $1512 \mathrm{~cm}^{-1}$.

\subsection{Crosslinking of Epoxy-Oligoesteric $M$ ixtures in the Presence of DCDER}

The synthesized DCDER contains the fragment of dianic epoxy resin, free carboxy and secondary hydroxy groups. To our mind, it is possible to use the synthesized product as an active additive to epoxy-oligoesteric mixtures, the crosslinking of which is carried out in the presence of PEPA, instead of TGM-3 oligoesteracrylate, usually used in industry.

The crosslinking of epoxy-oligoesteric mixtures was studied at room temperature, as well as at heating. In the case of heating the crosslinking was carried out stepwise: first at room temperature for $24 \mathrm{~h}$ and then at 383,403 or $423 \mathrm{~K}$ for $75 \mathrm{~min}$. The standard industrial mixture with TGM-3 (mixture I) was taken for the comparison. The composition of epoxy-oligoesteric mixtures, which were crosslinked at room temperature according to the procedure described in Subsection 2, is given in Table 1; the results concerning hardness and gelfraction content - in Fig. 2.
It is obvious from Fig. 2 that after $24 \mathrm{~h}$ the films are hard and contain sufficiently high amount of insoluble products. After 7 days the hardness and gel-fraction content of the mixture II increases slightly, whereas for the mixture I both values continue to increase even after 7 days. This fact points that for the mixture I the threedimensional polymerization of TGM-3 molecules takes place by double unsaturated bonds under the influence of air oxygen in addition to interaction between epoxy groups of ED-20 resin and amine groups of PEPA. For the mixture II, apart from the main interaction between ED-20 and PEPA molecules, the epoxy groups of ED-20 react with the carboxy groups of DCDER. These carboxy groups catalyze the reaction. The process is finished after 7 days (Fig. 2).

When comparing the experimental results for both mixtures we observe the higher values of hardness and gel-fraction content for the mixture II. So, DCDER may be used as an active additive for epoxy-oligoesteric mixtures, the crosslinking of which takes place in the presence of PEPA, and as a plasticizer instead of TGM-3.

The next step was investigation of crosslinking of epoxy-oligoesteric mixtures which contain both TGM-3 oligoesteracrylate and DCDER at heating (Table 2). The mixtures with DCDER only (mixture VI, Table II) and standard industrial mixture with TGM-3 (mixture I, Table 1) were taken for the comparison.

The results regarding hardness and gel-fraction content are represented in Tables 3-5. These results confirm that both values depend on epoxy-oligoesteric mixtures composition, as well as crosslinking temperature and time.

With the increase in DCDER amount to $40 \mathrm{wt} \%$ (mixture V) the films remain soft at $383 \mathrm{~K}$ for $75 \mathrm{~min}$ (Table 3). The same results were obtained at 403 for 45 min (Table 4) and $423 \mathrm{~K}$ for $30 \mathrm{~min}$ (Table 5). However, the gel-fraction content of the mixture $\mathrm{V}$ is sufficiently high within all investigated intervals (Tables 3-5). 


\section{Composition of epoxy-oligoesteric mixtures}

\begin{tabular}{|l|c|c|}
\hline \multicolumn{1}{|c|}{ Component } & \multicolumn{2}{c}{ Component content, wt \% } \\
\cline { 2 - 3 } & I & \\
\hline ED-20 epoxy resin & 90 & \\
\hline DCDER & - & 10 \\
\hline TGM-3 & 10 & 10 \\
\hline PEPA & 12.6 & - \\
\hline
\end{tabular}

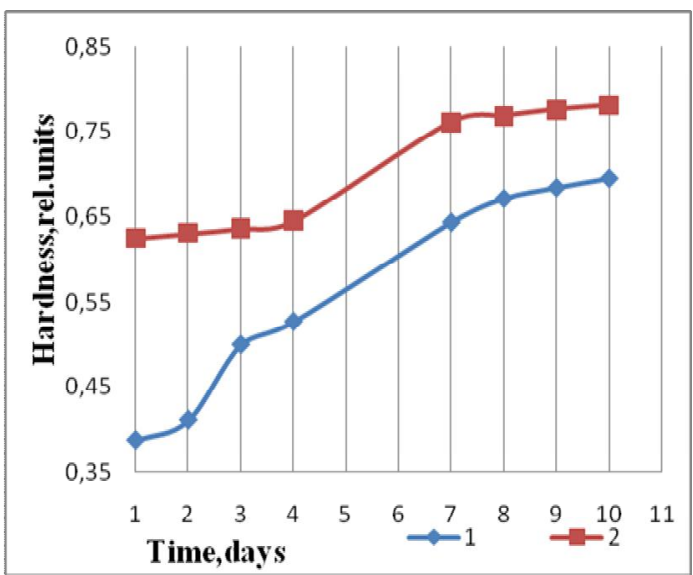

a)

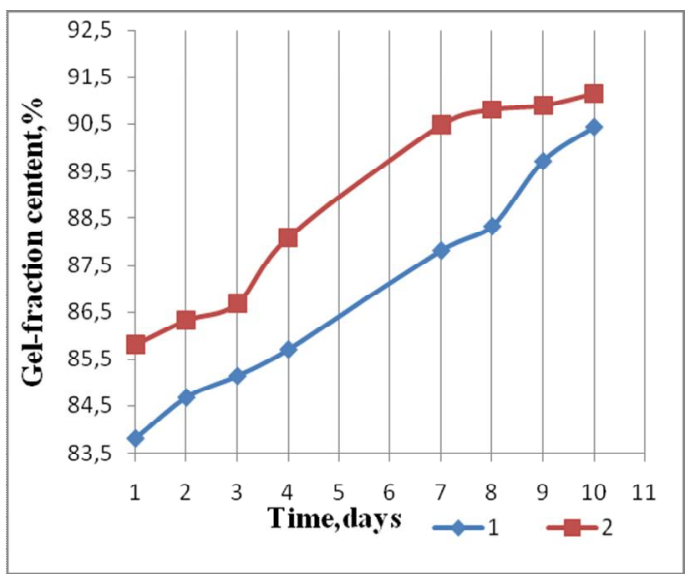

b)

Fig. 2. Dependence of film hardness (a) and gel-fraction content (b) on crosslinking time for the mixtures I (1) and II (2)

Table 2

\section{Composition of epoxy-oligoesteric mixtures}

\begin{tabular}{|l|c|c|c|c|}
\hline \multirow{2}{*}{ Component } & \multicolumn{4}{|c|}{ Components content, wt \% } \\
\cline { 2 - 5 } & III & IV & V & VI \\
\hline ED-20 epoxy resin & 90 & 80 & 60 & 60 \\
\hline DCDER & 10 & 20 & 40 & 40 \\
\hline TGM-3 & 10 & 20 & 10 & - \\
\hline PEPA & 12.6 & 11.0 & 9.0 & 9.0 \\
\hline
\end{tabular}

Note: PEPA amount was calculated according to the content of epoxy groups in the mixture. 14 wt \% PEPA was used for $100 \mathrm{~g}$ of ED-20

Table 3

Dependence of film hardness $(H)$ and gel-fraction $(G)$ on the mixture composition and crosslinking time at $383 \mathrm{~K}$

\begin{tabular}{|c|c|c|c|c|c|c|c|}
\hline \multirow{2}{*}{$\begin{array}{c}\text { Number } \\
\text { of mixture } \\
\text { according } \\
\text { to Table } 2 \\
\end{array}$} & \multirow[b]{2}{*}{ Index } & \multicolumn{6}{|c|}{ Index values for crosslinking time, min } \\
\hline & & $\begin{array}{l}24 \mathrm{~h} \text {, room } \\
\text { temperature }\end{array}$ & 15 & 30 & 45 & 60 & 75 \\
\hline \multirow{2}{*}{ III } & $H$ & 0.11 & 0.50 & 0.67 & 0.75 & 0.79 & 0.85 \\
\hline & $G$ & 74.8 & 87.3 & 89.1 & 89.9 & 90.4 & 91.1 \\
\hline \multirow{2}{*}{ IV } & $H$ & 0.03 & 0.23 & 0.29 & 0.43 & 0.45 & 0.59 \\
\hline & $G$ & 70.1 & 87.0 & 88.9 & 89.9 & 91.6 & 92.2 \\
\hline \multirow{2}{*}{ V } & $H$ & 0.0 & 0.0 & 0.0 & 0.0 & 0.0 & 0.0 \\
\hline & $G$ & 49.6 & 57.4 & 63.3 & 71.4 & 71.8 & 72.0 \\
\hline \multirow{2}{*}{ VI } & $H$ & 0.0 & 0.43 & 0.54 & 0.55 & 0.66 & 0.71 \\
\hline & $G$ & 45.7 & 68.2 & 74.8 & 80.2 & 82.6 & 86.6 \\
\hline
\end{tabular}


Dependence of film hardness $(H)$ and gel-fraction $(G)$ on the mixture composition and crosslinking time at $403 \mathrm{~K}$

\begin{tabular}{|c|c|c|c|c|c|c|c|}
\hline \multirow{2}{*}{$\begin{array}{c}\text { Number } \\
\text { of mixture } \\
\text { according } \\
\text { to Table } 2\end{array}$} & \multirow[b]{2}{*}{ Index } & \multicolumn{6}{|c|}{ Index values for crosslinking time, min } \\
\hline & & $\begin{array}{l}24 \mathrm{~h} \text {, room } \\
\text { temperature }\end{array}$ & 15 & 30 & 45 & 60 & 75 \\
\hline \multirow{2}{*}{ III } & $H$ & 0.11 & 0.70 & 0.76 & 0.81 & 0.84 & 0.92 \\
\hline & $G$ & 74.8 & 88.5 & 90.0 & 90.6 & 91.4 & 91.5 \\
\hline \multirow{2}{*}{ IV } & $H$ & 0.03 & 0.43 & 0.46 & 0.56 & 0.57 & 0.66 \\
\hline & $G$ & 70.1 & 86.1 & 86.5 & 89.6 & 89.9 & 90.2 \\
\hline \multirow{2}{*}{$\mathrm{V}$} & $H$ & 0.0 & 0.0 & 0.0 & 0.06 & 0.19 & 0.27 \\
\hline & $G$ & 49.6 & 65.5 & 68.3 & 73.4 & 75.6 & 77.3 \\
\hline \multirow{2}{*}{ VI } & $H$ & 0.0 & 0.47 & 0.58 & 0.62 & 0.67 & 0.72 \\
\hline & $G$ & 45.7 & 76.6 & 88.1 & 89.0 & 91.4 & 94.0 \\
\hline \multirow{2}{*}{ I } & $H$ & 0.36 & 0.39 & 0.46 & 0.62 & 0.72 & 0.75 \\
\hline & $G$ & 83.7 & 94.4 & 94.7 & 97.2 & 99.1 & 99.4 \\
\hline
\end{tabular}

Note: the mixture I is given here for the comparison

Dependence of film hardness $(H)$ and gel-fraction $(G)$ on the mixture composition and crosslinking time at $423 \mathrm{~K}$

\begin{tabular}{|c|c|c|c|c|c|c|c|}
\hline \multirow{2}{*}{$\begin{array}{c}\text { Number } \\
\text { of mixture } \\
\text { according } \\
\text { to Table } 2\end{array}$} & \multirow[b]{2}{*}{ Index } & \multicolumn{6}{|c|}{ Index values for crosslinking time, $\min$} \\
\hline & & $\begin{array}{l}24 \mathrm{~h} \text {, room } \\
\text { temperature }\end{array}$ & 15 & 30 & 45 & 60 & 75 \\
\hline \multirow{2}{*}{ III } & $H$ & 0.11 & 0.75 & 0.78 & 0.86 & 0.89 & 0.93 \\
\hline & $G$ & 74.8 & 89.4 & 91.2 & 92.4 & 92.9 & 93.4 \\
\hline \multirow{2}{*}{ IV } & $H$ & 0.03 & 0.44 & 0.50 & 0.57 & 0.68 & 0.76 \\
\hline & $G$ & 70.1 & 88.7 & 90.1 & 91.0 & 92.3 & 93.4 \\
\hline \multirow{2}{*}{ V } & $H$ & 0.0 & 0.0 & 0.0 & 0.42 & 0.43 & 0.46 \\
\hline & $G$ & 49.6 & 68.2 & 75.0 & 75.1 & 78.7 & 79.8 \\
\hline \multirow{2}{*}{ VI } & $H$ & 0.0 & 0.52 & 0.58 & 0.63 & 0.72 & 0.78 \\
\hline & $G$ & 45.7 & 90.9 & 91.8 & 94.1 & 95.8 & 97.0 \\
\hline
\end{tabular}

For the mixture VI, which contains the same amount of DCDER but does not contain TGM-3, the films remain soft only in the case of crosslinking at room temperature for $24 \mathrm{~h}$ and at initial heating. It means that while forming polymeric films under mentioned conditions only PEPA participates in the crosslinking of ED-20 molecules. TGM-3 and DCDER molecules actually do not participate in the formation of crosslinked structure. The increase in temperature and crosslinking time results in the reaction of free carboxy groups of DCDER with free epoxy and hydroxy groups of ED-20 resin. Such interaction leads to the increase in film hardness and gel-fraction content. At the same time the increase in temperature and crosslinking time makes possible the three-dimensional polymerization of TGM-3 molecules, also leading to the increase of abovementioned values.

The decrease in DCDER amount (mixture III) slightly influences the hardness and gel-fraction content.
In such a case the crosslinking takes place due to the reaction between ED-20 and PEPA. When comparing the results for the mixture III (with DCDER) and standard industrial mixture I (Table 4) we observe that DCDER decreases the film hardness while crosslinking at room temperature but considerably increases it at heating. Moreover, gel-fraction content for the mixture III is lower compared with that for the mixture I. This fact reveals that under mentioned conditions the DCDER molecules only partially participate in a crosslinking process. If we compare the results for the mixture III at $403 \mathrm{~K}$ (Table 4) and $423 \mathrm{~K}$ (Table 5), we observe that the increase in temperature does not affect the values of hardness and gel-fraction content. Thus, the temperature of $403 \mathrm{~K}$ and time of 60-75 min were found to be the optimal values for crosslinking. The resulting films have hardness of 0.84 0.92 rel.units and gel-fraction content of $91.4-91.5 \%$. It should be noted that adhesion of the films is equal to "one" (cross-cut method was used). 
To confirm the above-mentioned statement about the chemistry of films formation at different temperatures we used IR-spectroscopy. The structural changes were controlled for the mixture III according to the absorption bands at $918 \mathrm{~cm}^{-1}$, corresponding to stretching vibrations of epoxy ring; at $3320 \mathrm{~cm}^{-1}$ - stretching vibrations of hydroxy group; at $1608 \mathrm{~cm}^{-1}$ - stretching vibrations of double bond; at $1720 \mathrm{~cm}^{-1}-$ stretching vibrations of carbonyl

Fig. 3. IR-spectra of epoxy-oligoesteric mixture III after its preparing (1) and after crosslinking at $423 \mathrm{~K}$ for $75 \mathrm{~min}(2)$

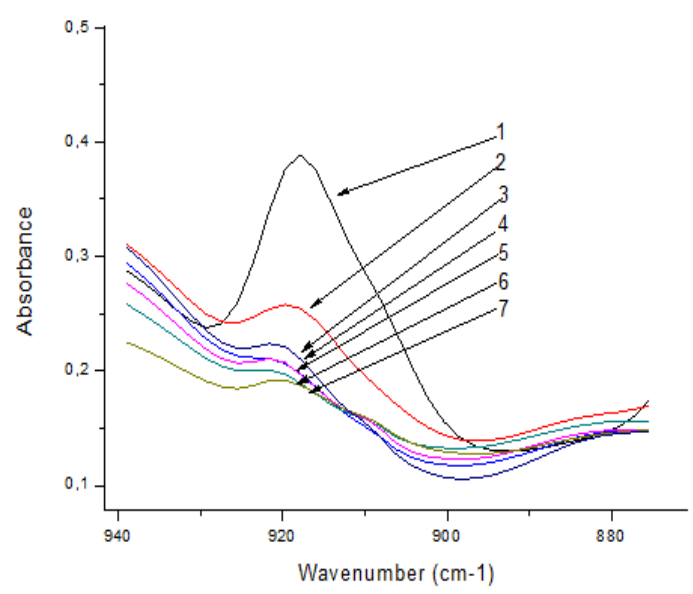

a) group and at $1720 \mathrm{~cm}^{-1}$ - stretching vibrations of $\mathrm{C}-\mathrm{O}-\mathrm{C}$ group in $-\mathrm{C}-\mathrm{O}-\mathrm{C}-$ esteric fragment (Fig. 3).

It is observed from Figs. 4-5 that spectra recorded after preparing the mixture and its heating are different. Moreover, the intensity of absorption bands of definite functional groups depends not only on the process temperature but on crosslinking time as well.
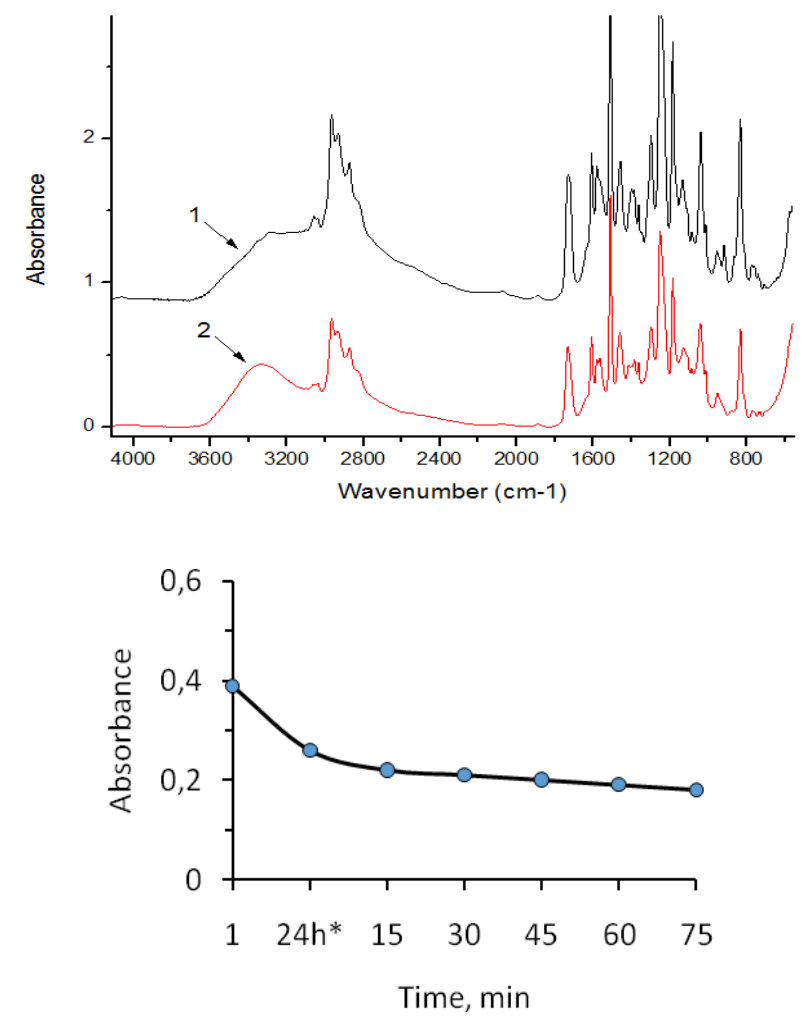

b)

Fig. 4. Absorption band at $918 \mathrm{~cm}^{-1}$ (a) and change of its intensity (b) after preparing the mixture III (1), after keeping at room temperature for $24 \mathrm{~h} \mathrm{(2)}$ and after heating at $383 \mathrm{~K}$ for 15 (3); 30 (4); 45 (5); 60 (6) and 75 (7) min

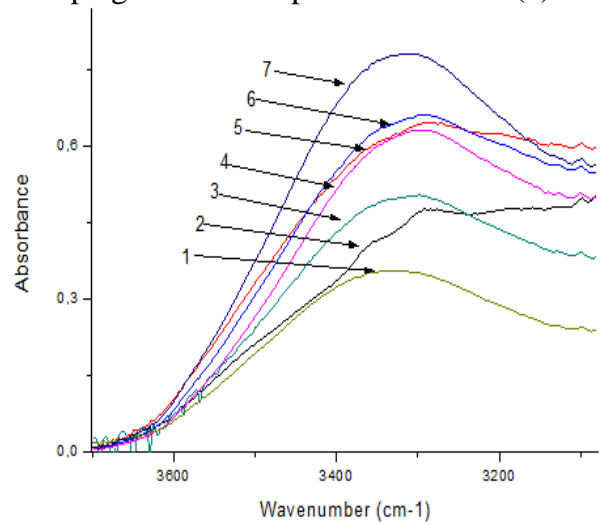

a)

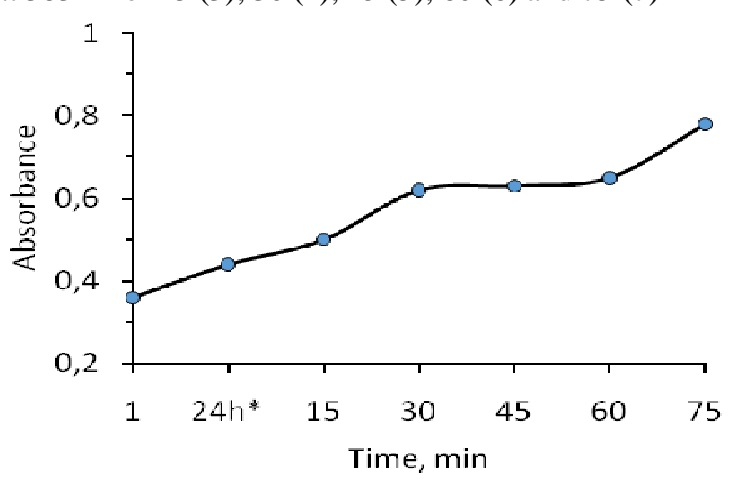

b)

Fig. 5. Absorption band at $3320 \mathrm{~cm}^{-1}$ (a) and change of its intensity (b) after preparing the mixture III (1), after keeping at room temperature for $24 \mathrm{~h}(2)$ and after heating at $383 \mathrm{~K}$ for 15 (3); 30 (4); 45 (5); 60 (6) and 75 (7) $\mathrm{min}$ 


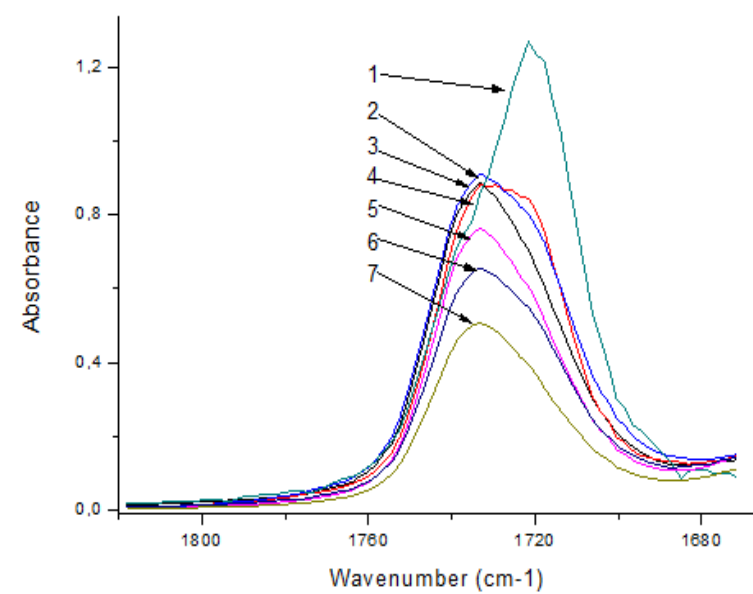

a)

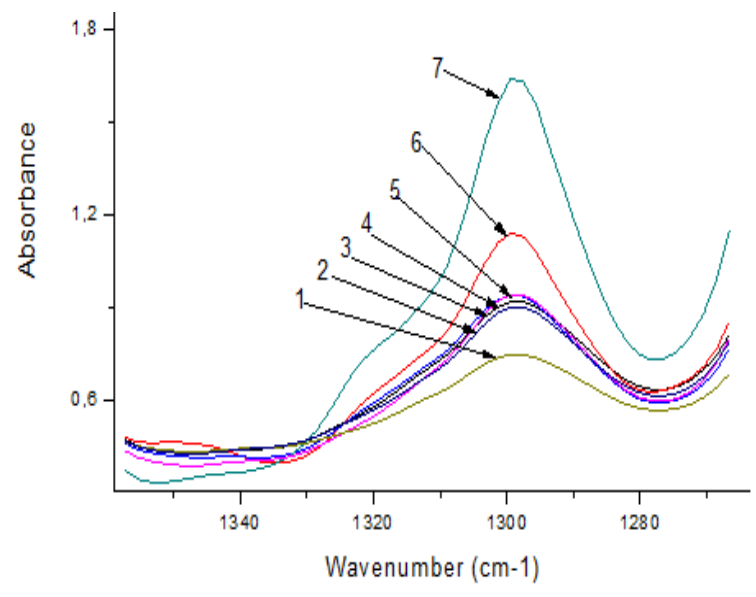

b)

Fig. 6. Absorption band of carbonyl group at $1720 \mathrm{~cm}^{-1}$ (a) and $-\mathrm{C}-\mathrm{O}-\mathrm{C}-$ group in esteric fragment at $1290 \mathrm{~cm}^{-1}$ (b) after preparing the mixture III (1), after keeping at room temperature for $24 \mathrm{~h} \mathrm{(2)}$ and after heating at $403 \mathrm{~K}$ for $15(3) ; 30(4) ; 45(5) ; 60(6)$ and $75(7) \mathrm{min}$

While forming films at room temperature for $24 \mathrm{~h}$ (curve 2, Fig. 4) the decrease in band intensity is evident; after heating the band disappears. It means that under the experimental conditions the epoxy groups of ED-20 react with PEPA molecules. As a result, the epoxy ring is opened and hydroxy groups are formed (see Fig. 5).

The participation of DCDER molecules in a crosslinking process is confirmed by the results presented in Fig. 6. At room temperature we observe the decrease in intensity of absorption band at $1720 \mathrm{~cm}^{-1}$ corresponding to a carbonyl group (Fig. 6a) and the increase in intensity of the band at $1290 \mathrm{~cm}^{-1}$ corresponding to $-\mathrm{C}-\mathrm{O}-\mathrm{C}$ group in an esteric fragment (Fig. 6b). After heating the absorption band shifts from 1720 to $1735 \mathrm{~cm}^{-1}$ (Fig. 6a) indicating the transfer of carbonyl bond from carboxy group to the bond in esters. It points to the chemical reaction between carboxy groups of the synthesized DCDER and epoxy groups of ED-20 epoxy resin according to Eq. (3):<smiles>CC(=O)OC(=O)OCCCCCCCC(=O)OC(C)O</smiles>

The possible formation of esteric fragment according to Eq. (3) is confirmed by the increase in intensity of absorption band at $1290 \mathrm{~cm}^{-1}$ (Fig. 6b).

The participation of TGM-3 molecules in the crosslinking process is confirmed by the results presented in Fig. 7.

It is observed from Fig. 7 that a partial polymerization of double bonds in TGM-3 occurs already at room temperature due to the exothermic reaction between ED-20 and PEPA molecules. Further heating of the mixture to $423 \mathrm{~K}$ decreases the intensity of absorption band at $1608 \mathrm{~cm}^{-1}$. This fact indicates further threedimensional polymerization of TGM-3 molecules in the matrix formed by ED-20 and DCDER molecules due to their reaction with PEPA and between each other.

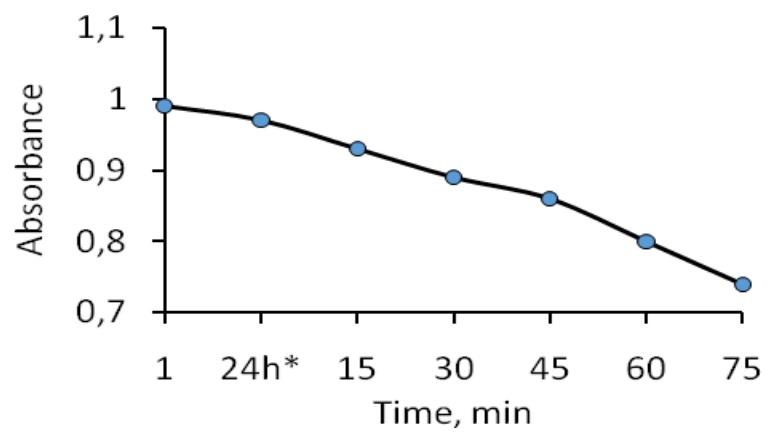

Fig. 7. Change of absorption band intensity at $1608 \mathrm{~cm}^{-1}$ after preparing the mixture III (1 min), after keeping at room temperature $(24 \mathrm{~h})$ and after heating at $423 \mathrm{~K}$ $(15,30,45,60,75 \mathrm{~min})$

Thus, at room temperature the crosslinking of epoxy-oligoesteric mixtures occurs due to the reaction between ED-20, DCDER and PEPA molecules. Under these conditions the partial polymerization of TGM-3 molecules also takes place. TGM-3 is not chemically bounded with the main matrix formed by ED-20 and DCDER molecules. Heating of the mixtures results in further formation of crosslinked molecules due to the reaction between free carboxy groups of DCDER and epoxy or hydroxy groups of the initial ED-20 and already crosslinked ED-20 as well. Moreover, at heating the threedimensional polymerization of TGM-3 molecules takes place, that is confirmed by IR-spectroscopy (Fig. 7, Table 4). 


\section{Conclusions}

New oligomeric compound (DCDER) has been synthesized in accordance with the reaction between the dioxydiphenylpropane diglycidyl ether and adipic acid. The synthesized compound does not contain epoxy groups but has free carboxy groups at the ends of its chain. The structure of DCDER was confirmed by the chemical analysis and IR-spectroscopy. The presence of hydroxy groups was confirmed by the absorption band at $3320 \mathrm{~cm}^{-}$ ${ }^{1}$, esteric bond - by the bands at 1720 and $1290 \mathrm{~cm}^{-1}$.

The synthesized DCDER has been studied as an active additive to epoxy-oligoesteric mixtures composed of ED-20 dianic epoxy resin and TGM-3 oligoesteracrylate, the crosslinking of which was carried out in the presence of PEPA as the hardener. The films with DCDER (10 wt \%) which were crosslinked at room temperature have improved characteristics compared with the films containing TGM-3. At stepwise crosslinking (first at room temperature for $24 \mathrm{~h}$; then at heating to 383 , 403 or $423 \mathrm{~K}$ for $75 \mathrm{~min}$ ) the films hardness and gelfraction content depend on DCDER amount in the mixture, temperature and crosslinking time.

IR-spectroscopy confirms the participation of all components in the formation of polymeric films based on epoxy-oligoesteric mixtures with DCDER.

\section{References}

[1] Prokopchuk N., Krutko E.: Khymyia i Tekhnolohyia Plenkoobrazuiushchykh Veshchestv. BGTU, Minsk 2004.

[2] Bratychak M., Hetmanchuk Yu.: Khimichna Technologiia Syntezu Vysokomolekuliarnykh Spoluk. Vyd-vo Lviv Polytechnic National University, Lviv 2009.

[3] Moshinsky L.: Epoxy Resins and Hardeners. Structure, Properties, Chemistry and Topology of Curing. Arcadia press Ltd., Tel-Aviv 1995.

[4] Fink J.K: Reactive Polymers Fundamentals and Applications, William Andrew Inc., 2005.
[5] Bratychak M., Bratychak Mykh.: Peroksydni Pokhidni Epoksydnykh Smol. Vyd-vo Lviv Polytechnic National University, Lviv 2003.

[6] Bashta B., Astakhova O., Shyshchak O. et al.: Chem. Chem. Technol., 2014, 8, 309.

[7] Iatsyshyn O., Astakhova O., Lazorko O. et al.: Chem. Chem. Technol., 2013, 7, 73 .

[8] Ivashkiv O., Astakhova O., Shyshchak O. et al.: Chem. Chem. Technol., 2015, 9, 69.

[9] Ivashkiv O., Namiesnik J., Astakhova O. et al.: Chem. Chem. Technol., 2015, 9, 313.

[10] Bratychak M., Chervinskii T., Gagin M. et al.: Ukr. Khim. Zh., 2005, 71, 50 .

[11] Toroptseva A., Belgorodskaya K., Bondarenko V.: Laboratornyi Praktykum po Khimii i Tekhnologii Vysokomolekuliarnykh Soedynenyi. Khimiia, Leningrad 1972.

[12] Metody ispytanyi lakov i krasok. Opredelenie tverdosti plenki po mayatnikovomy priboru. Izdatelstvo standartov, Moskva 2003.

[13] Ivanov V.: Rukovodstvo po Khimii Polymerov. Izd-vo Leningradskogo Univ., Leningrad 1982.

Received: December 12, 2016 / Revised: December 24, 2016 / Accepted: J anuary 15, 2017

\section{СТРУКТУРУВАННЯ ЕПОКСИ-ОЛІГОЕСТЕРНИХ СУМНШЕЙ В ПРИСУТНОСТІ МОДИФІКОВАНОГО АДИПІНОВОЮ КИСЛОТОЮ ДИГЛШЦИДЛОВОГО ЕТЕРУ ДІОКСИДИФЕНІЛПРОПАНУ}

Анотація. Вивчено структурування епокси-олігоестерних сумішей, що складаються із діанової епоксидної смоли ED-20 i олігоестеракрилату TGM-3 в присутності модифікованого адипіновою кислотою дигліциділового етеру діоксидифенілпропану (ДЕДФП). Структурування проводили як за кімнатної температури, так $i$ за нагрівання при 383, 403 або 423 К з використанням як затвердни поліетиленполіаміну. Наведена методика синтезу ДЕДФП. Контроль за структурними змінами в процесі формування полімерних плівок проводили за визначенням їх твердості та вмісту гельфракиій. За допомогою ІЧ-спектроскопічних досліджень встановлено хімізм формування полімерних плівок.

Ключові слова: структурування, полімерні плівки, епоксидна смола, олігоестеракрилат, твердість, гель-фракція, ІЧ-спектроскопія. 